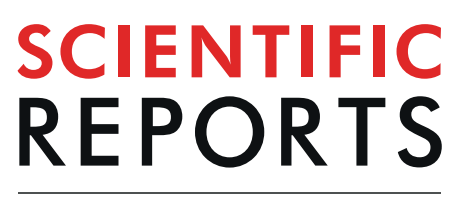

natureresearch

Check for updates

\title{
Nutritional value, antioxidant and antidiabetic properties of nettles (Laportea alatipes and Obetia tenax)
}

\begin{abstract}
Nomfundo Thobeka Mahlangeni $\mathbb{D}$, Roshila Moodley ${ }^{凶}$ \& Sreekantha Babu Jonnalagadda $(\mathbb{D}$
Nettles are commonly consumed in South Africa, Europe and Asia and are used in traditional medicine to treat a variety of ailments. In this study, the nutritional value of the leaves of nettles (Laportea alatipes and Obetia tenax) was evaluated and compared, when cooked and uncooked. The results showed a decrease in the concentrations of crude protein, vitamin $A$, vitamin $E$ and metals after cooking of nettles. Although cooking reduced the concentrations of essential elements in nettles, their contribution to the diet remained adequate. $L$. alatipes presented with reduced levels of $\mathrm{Cd}$ (from 1.86 to $0.810 \mathrm{mg} \mathrm{kg}^{-1}$ ) and $\mathrm{Pb}$ (from 2.87 to $1.88 \mathrm{mg} \mathrm{kg}^{-1}$ ) after cooking. Similarly, Cd (from 2.97 to $0.780 \mathrm{mg} \mathrm{kg}^{-1}$ ) and $\mathrm{Pb}$ (from 2.21 to $0.795 \mathrm{mg} \mathrm{kg}^{-1}$ ) levels in 0 . tenax decreased after cooking, demonstrating the significance of cooking. The antioxidant activity of the nettles was determined using the 2,2-diphenyl-I-picrylhydrazyl (DPPH) free radical and ferric reducing antioxidant power (FRAP) assays. The methanol extract of Obetia tenax showed high ferric reducing power whilst the radical scavenging activity was due to the presence of the bioactive molecule, $\beta$-carotene, in the plants which exhibited higher DPPH radical scavenging ability relative to test samples and standards. The in vitro antidiabetic activity of the extracts and compounds from the nettles was better than or comparable to that of the known standard, acarbose, which underscores the prospective antidiabetic properties of nettles. Overall, our study provides scientific validation for the ethno-medicinal use of nettles and supports their consumption, which highlights their potential as nutraceuticals.
\end{abstract}

Malnutrition results from inadequate intake of food or an improper diet and it affects normal functioning of the human body as well as growth and development in children ${ }^{1}$. Malnutrition is a serious health concern in developing countries such as Asia, Africa, Latin America and the Middle East with one in five people being malnourished and experiencing the conditions associated with micronutrient deficiencies ${ }^{2}$. For proper nourishment, the human body needs foods rich in macronutrients (carbohydrates, fats, proteins and vitamins) and minerals but low in sugar. In South Africa, non-communicable diseases (NCDs) such as cardiovascular disease, chronic respiratory disease and cancer account for $37 \%$ of deaths. The World Health Organization (WHO) has therefore suggested a daily intake of $400 \mathrm{~g}$ of fruits and vegetable per day to reduce the risk of NCDs ${ }^{3,4}$.

Food insecurity also plays a role in malnutrition as nutritious foods are inaccessible, unaffordable or unavailable. Leafy green vegetables are important in developing countries because they are cheap, readily available, nutritious and easy to cook. These leafy green vegetables contain substantial amounts of antioxidant vitamins $(\beta$-carotene, vitamin $\mathrm{C}$ and $\mathrm{E})$ and minerals ${ }^{5}$.

Diabetes mellitus is a metabolic disorder characterized by hyperglycemia (high blood glucose) resulting in defects in the secretion of insulin, impaired action of insulin or both ${ }^{6}$. In the absence of insulin, glucose (from broken down carbohydrates and starch) builds up in blood vessels as it cannot be absorbed into the cells of the body which results in organ and tissue failure. The International Federation of Diabetes (IDF) reported that about 15.9 million have diabetes in Africa, and expected to increase by more than $100 \%$ in $2045^{7}$. South Africa is amongst the top five countries with the highest number of people living with diabetes ${ }^{7}$.

The growing popularity of nutraceuticals has led to a greater demand for the identification of new plants that are both nutritional and medicinal. Laportea alatipes Hook. f. and Obetia tenax (N.E.Br.) Friis are from the 


\begin{tabular}{|c|c|c|c|c|c|c|c|c|c|c|}
\hline & \multicolumn{2}{|l|}{ Laportea alatipes } & \multicolumn{2}{|l|}{ Obetia tenax } & \multicolumn{2}{|l|}{ DRI } & \multirow{2}{*}{\begin{tabular}{|l|} 
L. alatipes \\
UC/C \\
\end{tabular}} & \multirow{2}{*}{$\begin{array}{l}\text { O. tenax } \\
\mathrm{UC} / \mathrm{C} \\
\end{array}$} & \multirow{2}{*}{\begin{tabular}{|l|} 
L. peduncularis \\
UC/C \\
\end{tabular}} & \multirow{2}{*}{\begin{tabular}{|l|} 
U. dioica \\
UC/C \\
\end{tabular}} \\
\hline & UC & C & UC & C & \multirow{2}{*}{$\begin{array}{l}\mathrm{RDA}^{\mathrm{b}} \text { (mg } \\
\text { per day) }\end{array}$} & \multirow{2}{*}{$\begin{array}{l}\mathrm{DV}^{\mathrm{c}} \\
(\mathrm{mg})\end{array}$} & & & & \\
\hline \multicolumn{5}{|c|}{$\left(\mathrm{mg} \mathrm{kg}^{-1}\right)$} & & & \multicolumn{4}{|l|}{ (mg per 60g) } \\
\hline \multicolumn{11}{|c|}{ Macro-elements } \\
\hline $\mathrm{Ca}$ & $34084 \pm 1074 \mathrm{ca}$ & $12652 \pm 1598 \mathrm{a}$ & $21999 \pm 1618 b$ & $21620 \pm 636 \mathrm{~b}$ & $1000-1300$ & 1000 & $2045 / 759$ & $1320 / 1297$ & $1654 / 770$ & $1899 / 871$ \\
\hline $\mathrm{Fe}$ & $57115 \pm 6413 c$ & $39196 \pm 5376 a$ & $112534 \pm 9902 \mathrm{~d}$ & $16807 \pm 2035 b$ & $8-18$ & 18 & $3427 / 2352$ & $6752 / 1008$ & \begin{tabular}{|l|l|}
$78.7 / 60.6$ \\
\end{tabular} & $12.5 / 19.1$ \\
\hline $\mathrm{Mg}$ & $12407 \pm 432 \mathrm{c}$ & $2023 \pm 212 \mathrm{a}$ & $10648 \pm 544 \mathrm{~d}$ & $4075 \pm 155 b$ & $240-400$ & 400 & $744 / 121$ & $639 / 245$ & $420 / 142$ & $371 / 136$ \\
\hline $\mathrm{P}$ & $1715 \pm 108 \mathrm{c}$ & $1264 \pm 112 \mathrm{a}$ & $1340 \pm 74.6 \mathrm{~d}$ & $1135 \pm 153 b$ & & 1000 & & & & \\
\hline \multicolumn{11}{|c|}{ Micro-elements } \\
\hline $\mathrm{Ba}$ & $77.0 \pm 5.22 \mathrm{~b}$ & $57.7 \pm 6.26 \mathrm{a}$ & $151 \pm 7.41 \mathrm{c}$ & $88.1 \pm 5.00 \mathrm{~b}$ & & & & & & \\
\hline Co & $1.74 \pm 0.26 \mathrm{a}$ & $1.50 \pm 0.19 \mathrm{a}$ & $6.64 \pm 0.430 \mathrm{c}$ & $0.845 \pm 0.118 \mathrm{~b}$ & & & & & & \\
\hline $\mathrm{Cr}$ & $12.1 \pm 1.32 \mathrm{~b}$ & $0.073 \pm 0 \mathrm{a}$ & $87.7 \pm 6.11 c$ & $0.074 \pm 0.001 \mathrm{a}$ & $0.02-0.035$ & 0.120 & $0.726 / 0.004$ & $5.26 / 0.004$ & $0.186 / 0.407$ & $0.063 / 0.1$ \\
\hline $\mathrm{Cu}$ & $19.1 \pm 1.02 \mathrm{~b}$ & $12.8 \pm 0.59 \mathrm{a}$ & $23.9 \pm 2.01 \mathrm{c}$ & $14.0 \pm 0.86 \mathrm{a}$ & $0.7-0.9$ & 2 & $1.15 / 0.768$ & $1.43 / 0.840$ & $1.38 / 0.382$ & $1.05 / 0.97$ \\
\hline $\mathrm{Mn}$ & $260 \pm 18.2 c$ & $180 \pm 24.9 \mathrm{a}$ & $206 \pm 14.3 \mathrm{a}$ & $76.1 \pm 3.34 \mathrm{~b}$ & $1.6-2.3$ & 2 & $15.6 / 10.8$ & $12.4 / 4.57$ & $91.3 / 10.5$ & $1.53 / 2.93$ \\
\hline $\mathrm{Ni}$ & $11.8 \pm 0.95 \mathrm{~b}$ & $6.36 \pm 1.39 \mathrm{a}$ & $15.8 \pm 1.04 \mathrm{c}$ & $8.42 \pm 1.19 \mathrm{a}$ & ND & & $0.708 / 0.382$ & $0.948 / 0.505$ & $0.287 / 0.121$ & $0.144 / 0.03$ \\
\hline $\mathrm{Zn}$ & $60.7 \pm 4.51 \mathrm{c}$ & $50.9 \pm 4.31 \mathrm{a}$ & $34.3 \pm 0.705 \mathrm{~b}$ & $35.2 \pm 2.06 \mathrm{~b}$ & $8-11$ & 15 & $3.64 / 3.05$ & $2.06 / 2.11$ & $2.25 / 1.51$ & $1.9 / 1.6$ \\
\hline \multicolumn{11}{|c|}{ Toxic elements } \\
\hline $\mathrm{Cd}$ & $1.86 \pm 0.207 \mathrm{~b}$ & $0.810 \pm 0.168 \mathrm{a}$ & $2.97 \pm 0.177 \mathrm{c}$ & $0.780 \pm 0.167 \mathrm{a}$ & & & & & & \\
\hline $\mathrm{Pb}$ & $2.87 \pm 0.250 \mathrm{c}$ & $1.88 \pm 0.134 \mathrm{a}$ & $2.21 \pm 0.128 \mathrm{a}$ & $0.795 \pm 0.157 \mathrm{~b}$ & & & & & & \\
\hline
\end{tabular}

Table 1. Concentration $\left(\mathrm{mg} \mathrm{kg}^{-1}\right.$, mean $\left.\pm \mathrm{SD}, \mathrm{n}=4\right)$ of essential and toxic elements in L. alatipes and O. tenax leaves (uncooked (UC) and cooked (C)). ${ }^{a}$ Values in the same row with different letters are significantly different (Tukey's post hoc comparison, $p<0.05$ ), ' Indicates recommended dietary allowance ${ }^{14}$, 'Indicates daily values ${ }^{20}$, ${ }^{\mathrm{d}}$ Results of previous study ${ }^{10}$. Dietary reference intakes (DRIs) (recommended dietary allowance (RDAs) and daily values (DVs)) and average concentration (in mg per $60 \mathrm{~g}$, dry mass, $\mathrm{n}=4$ )) of essential elements in nettles (L. alatipes, O. tenax, L. peduncularis ${ }^{\mathrm{d}}$ and $U$. dioica ${ }^{\mathrm{d}}$ ).

Urticaceae (nettle) family and are known for their nutritional and medicinal value. These nettles are found in KwaZulu-Natal, South Africa. They are generally known as forest nettle (L. alatipes) and mountain nettle (O. tenax) or Imbati in isiZulu. In traditional medicine, nettles are used to treat conditions such as rheumatoid arthritis, gout, eczema, benign prostatic hyperplasia, anemia, influenza, asthma and diabetes ${ }^{8,9}$.

Previously, we reported on the distribution of nutrients and anti-nutrients in the nettles, L. peduncularis susp. peduncularis and Urtica dioica ${ }^{10}$. In this study, we investigate the concentrations of nutrients and anti-nutrients in the nettles, L. alatipes and O. tenax and compare these values to those obtained from our previously study. The impact of cooking on nutritional value is also evaluated. Antioxidant and antidiabetic properties of the nettle extracts and isolated compounds were also investigated.

\section{Materials and Methods}

The materials and methods section is presented as Supplementary Material 1.

Human and animal studies. This article does not contain any studies with human or animal subjects.

\section{Results and Discussion}

Elemental analysis. On average, the moisture content of $L$. alatipes was found to be $79.2 \%$ and that of $O$. tenax was found to be $82.1 \%$. Food processing such as cooking alters the nutritional value of uncooked plant foods. For this reason, both uncooked and cooked leaves of $L$. alatipes and $O$. tenax was investigated for essential and toxic metal levels to determine their nutritional value and to assess for metal toxicities, respectively (Table 1).

Ingestion of toxic metals, even at low concentrations, can be detrimental to human health. Cadmium is known to target the kidneys and respiratory system ${ }^{11}$, and long-term exposure to $\mathrm{Pb}$ may cause damage to the nervous system and can lead to blood disorders ${ }^{12}$. Subsequently, the joint Food and Agriculture Organization of the United Nations (FAO) and WHO have set the maximum levels of $\mathrm{Cd}$ and $\mathrm{Pb}$ in leafy vegetables at $0.2 \mathrm{mg} \mathrm{kg}^{-1}$ and $0.3 \mathrm{mg} \mathrm{kg}^{-1}$, respectively ${ }^{13}$. In L. alatipes, Cd levels reduced by $56 \%$ from 1.86 to $0.810 \mathrm{mg} \mathrm{kg}^{-1}$ and $\mathrm{Pb}$ levels reduced by $34 \%$ from 2.87 to $1.88 \mathrm{mg} \mathrm{kg}^{-1}$ whilst in $O$. tenax, Cd levels reduced by $73 \%$ from 2.97 to $0.780 \mathrm{mg} \mathrm{kg}^{-1}$ and $\mathrm{Pb}$ levels reduced by $64 \%$ from 2.21 to $0.795 \mathrm{mg} \mathrm{kg}^{-1}$, after cooking. This study shows concentrations of toxic elements, $\mathrm{Cd}$ and $\mathrm{Pb}$, to decrease significantly after cooking which indicates the benefits of cooking leafy vegetables to reduce metal toxicities.

The results in Table 1 also show the concentrations of elements in $60 \mathrm{~g}$ (suggested serving size which is equivalent to two cups of spinach) of L. alatipes, O. tenax (this study), and L. peduncularis and U. dioica and their contribution to recommended dietary allowances (RDAs) and daily value (DVs) for the studied essential elements ${ }^{10,14}$. The estimated contribution to the diet by nettles can be used to assess for elemental value and deficiencies. Low fruit and vegetable intake by individuals has been a major contributor to micronutrient deficiencies, as a result, WHO has recommended consumption of a minimum of $400 \mathrm{~g}$ of fruits and vegetables per day ${ }^{15,16}$. Studies have shown that the average consumption of vegetables is less than $80 \mathrm{~g}$ per day in South Africa ${ }^{16,17}$. 


\begin{tabular}{|c|c|c|c|c|c|c|}
\hline & \multicolumn{4}{|c|}{ Average concentration in uncooked/cooked leaves (g per $60 \mathrm{~g}$, dry mass) } & \multicolumn{2}{|l|}{ DRI $^{\mathrm{a}}$} \\
\hline & LA & от & $\mathbf{L} \mathbf{P}^{\mathrm{b}}$ & $\mathbf{U D}^{\mathrm{b}}$ & $\begin{array}{l}\text { RDA (g per } \\
\text { day) }\end{array}$ & $\mathrm{DV}^{\mathrm{c}}(\mathrm{g})$ \\
\hline Carbohydrates & $35.1 / 35.7$ & $30.2 / 38.4$ & $12.9 / 27.7$ & $32.0 / 36.9$ & 130 & 300 \\
\hline Proteins & $3.22 / 2.94$ & $3.20 / 3.11$ & $0.82 / 1.07$ & $0.89 / 1.10$ & $34-56$ & 50 \\
\hline Vitamin $A^{d}$ & $9.9 \times 10^{-2} / 9.4 \times 10^{-4}$ & $1.1 \times 10^{-2} / 1.0 \times 10^{-2}$ & - & - & $\begin{array}{l}0.6 \times 10^{-3}- \\
0.9 \times 10^{-3}\end{array}$ & $\begin{array}{l}0.7 \times 10^{-3}- \\
0.9 \times 10^{-3}\end{array}$ \\
\hline Vitamin C & $0.023 / 0.022$ & $0.023 / 0.023$ & $0.011 / 0.010$ & $0.013 / 0.010$ & $0.045-0.075$ & 0.06 \\
\hline Vitamin E & $0.059 / 0.023$ & $0.067 / 0.021$ & $0.011 / 0.014$ & $0.016 / 0.015$ & $0.011-0.015$ & 0.020 \\
\hline
\end{tabular}

Table 2. Dietary reference intakes (DRIs) (recommended dietary allowances (RDAs) and daily values (DVs)) of macronutrients for most individuals and average concentrations of macronutrients $(\mathrm{n}=4)$ in L. alatipes (LA),

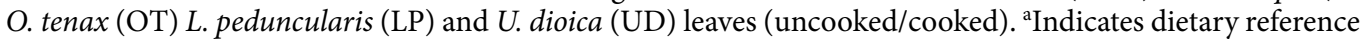
intakes ${ }^{14}$. ${ }^{b}$ Results of previous study ${ }^{10}$. Indicates daily values ${ }^{20}$. ${ }^{\mathrm{d}}$ Vitamin A as retinol; $1 \mu \mathrm{g} \beta$-carotene $=0.167 \mu \mathrm{g}$ retinol.

For the macro and micro-elemental content, the results showed a decrease in L. alatipes and O. tenax after cooking (Table 1). The most common elements that are deficient in humans are $\mathrm{Fe}, \mathrm{Zn}$ and $\mathrm{Cu}^{18}$. Disorders associated with $\mathrm{Zn}$ deficiencies include epilepsy, diabetes, multiple sclerosis, sickle-cell anemia and mood disorders. Insufficient dietary intake of $\mathrm{Cu}$ can lead to impaired Fe metabolism with hypochromic anemia and bone abnormalities. The results show nettles to be rich in Fe which would be beneficial to individuals who are suffering from Fe deficiency anemia ${ }^{19}$. After cooking, L. alatipes and O. tenax, respectively contribute $85 \%$ and $93 \%$ towards the RDA for $\mathrm{Cu}$, and $28 \%$ and $19 \%$ towards the RDA for $\mathrm{Zn}$. These values are much higher than those obtained for L. peduncularis ( $42 \% \mathrm{Cu}$ and $14 \% \mathrm{Zn})$ and comparable to those obtained for U. dioica $(108 \% \mathrm{Cu} \text { and } 14 \% \mathrm{Zn})^{10}$. The results also show L. alatipes and O. tenax, respectively to contribute $38 \%$ and $42 \%$ towards the DV for $\mathrm{Cu}$, and $20 \%$ and $14 \%$ towards the DV for $\mathrm{Zn}$, after cooking. This shows the nettles, L. alatipes and O. tenax, to be richer in essential elements compared to L. peduncularis and U. dioica.

The results of this study show that, while nettles contribute to the dietary reference intakes (DRIs) for essential elements for most individuals, this contribution is reduced on cooking due to leaching of elements into the cooking water. However, nettles were found to be nutritious, whether cooked or uncooked, with cooking being more beneficial due to reduction of toxic metal levels.

The results in Table 2 show the concentrations of macronutrients in the different nettles and their contribution to the RDA and DV for these nutrients. After cooking, L. alatipes and O. tenax, respectively contribute more to the RDA of proteins (5\% and 6\%), vitamin C (29\% and 31\%) and vitamin E (153\% and 140\%) compared to $L$. peduncularis and U. dioica ${ }^{10}$. A similar trend was observed for DVs. This study shows L. alatipes and O. tenax to have higher macronutrient content compared to L. peduncularis and U. dioica, after cooking.

Vitamin A deficiency has been shown to be a major nutrient deficiency in South Africa and has been linked to non-communicable diseases such as xerophthalmia, which is associated with dry eyes and night blindness. Vitamin C, an effective antioxidant, is a cofactor in numerous physiological reactions such as collagen gene expression, peptide hormone activation, and carnitine synthesis. Vitamin E is known for its antioxidant activity especially the inhibition of membrane lipid peroxidation ${ }^{21}$.

Of the three vitamins determined, only vitamin $\mathrm{C}$ was unaffected by cooking in all four nettles. A study conducted on the effect of cooking on vitamin $\mathrm{C}$ content of some selected vegetables showed highest loss of vitamin $\mathrm{C}$ in pepper (64.7\%) after 30 minutes and lowest loss of vitamin C in spinach (9.9\%) after 5 minutes ${ }^{22}$. Vitamin C, a water-soluble and heat labile substance will easily leach into water and then degrade by heat. Elevated temperatures and long cooking times have been found to cause loss of vitamin $\mathrm{C}^{23}$. In this study, there was high retention of vitamin $\mathrm{C}$ after 15 minutes of cooking. This could be due to shorter cooking times and low temperatures, which could have been inadequate for release of vitamin $\mathrm{C}$ from its intracellular locations.

Green leafy vegetables have higher retention of vitamin A than root vegetables, which may be attributed to its increased extractability following denaturation of proteins and a complete breakdown of the cell wall in plants which occur as a result of cooking ${ }^{22}$. In this study, there was lower retention of vitamin A and E after cooking of $O$. tenax and L. alatipes. Vitamin A is found in the photosynthetic pigment-protein complexes of chloroplasts in leafy green vegetables, which inhibit its extractability ${ }^{24}$. Green leafy vegetables have vitamin E occurring mainly as $\alpha$-tocopherol which is situated inside chloroplast ${ }^{25}$. Cooking could increase extractability by softening plant walls and disrupting protein complexes. Solubilization of vitamins A and E in cellular lipid emulsions formed during cooking could decrease retention by the leaves and lead to lower concentrations.

Antioxidant and antidiabetic activities. An antioxidant is a biochemical substance that protects living cells from damage caused by free radicals that can cause cancer, cardiovascular diseases and other age-related diseases. The 2,2-diphenyl-1-picrylhydrazyl (DPPH) assay is based on the measurement of the ability of antioxidants to scavenge the DPPH radical in solution as observed by a loss of color from deep violet to yellow ${ }^{26}$. In this study, the methanol $(\mathrm{MeOH})$ and dichloromethane (DCM) extracts, and isolated compounds, $\beta$-carotene and $\beta$-sitosterol from the nettles, L. alatipes and $O$. tenax, was evaluated for antioxidant activity. The extracts showed moderate inhibition of the DPPH radical relative to the known standards, ascorbic acid and $\alpha$-tocopherol (Fig. 1a). This was also observed in a previous study on the antioxidant activity of the ethanol and hot water extracts of Laportea interrupta ${ }^{27}$. The highest antioxidant activity was exhibited by $\beta$-carotene 
a)
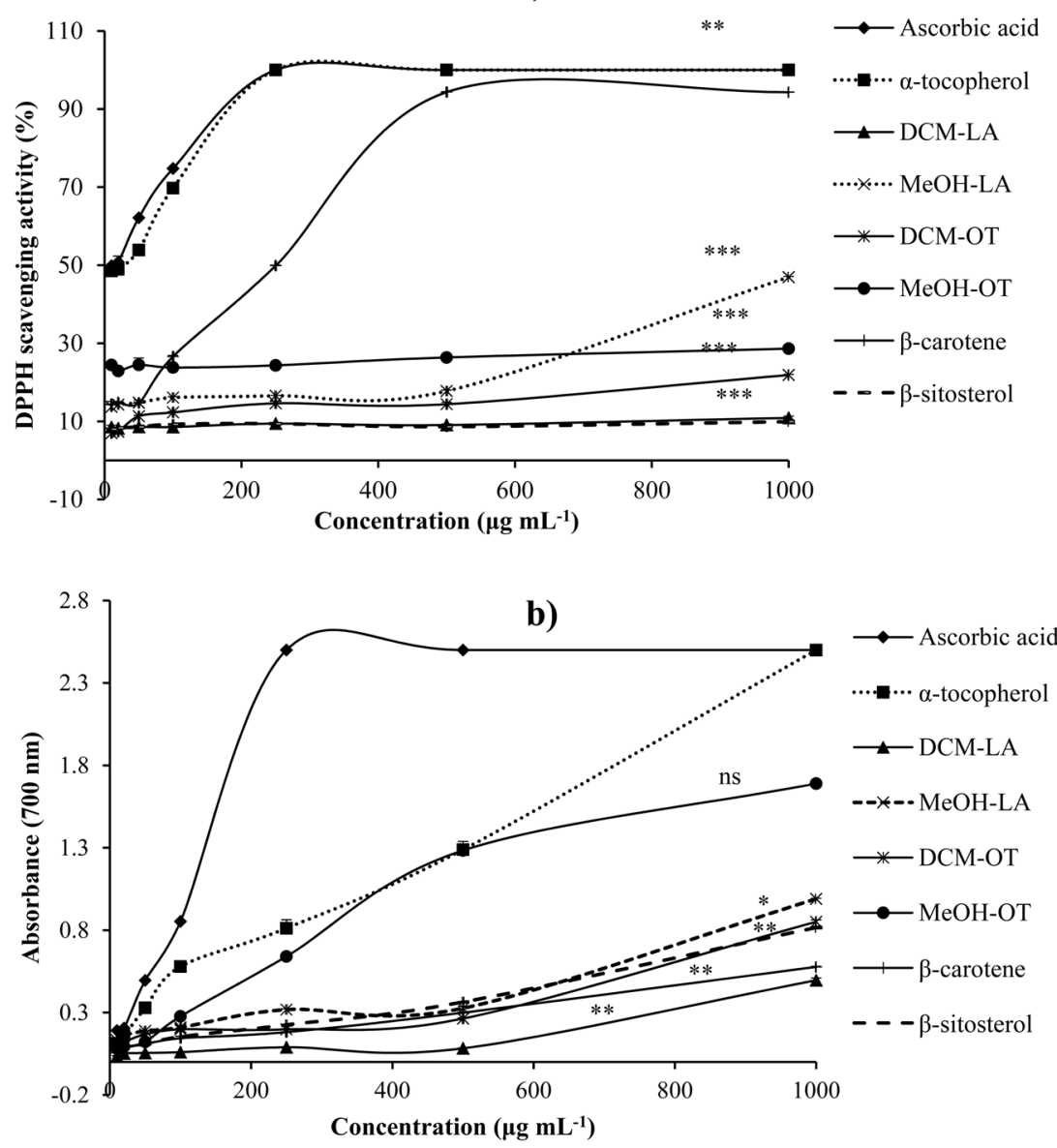

Figure 1. (a) DPPH radical scavenging activity and (b) Ferric reducing power of L. alatipes (LA), O. tenax (OT) and isolated compounds. Values represented as mean $\pm S D, n=3$. One way Anova and Dunnetts post hoc test shows significant difference from positive control, ascorbic acid, a) (** $p<0.01$ and $\left.{ }^{* * *} p<0.001\right)$, b) (ns-not significant, ${ }^{*} p<0.05$ and $\left.{ }^{*} p<0.01\right)$.

$\left(\mathrm{IC}_{50}=339 \mu \mathrm{g} \mathrm{mL} L^{-1}\right)$ when compared to the extracts and $\beta$-sitosterol, which was comparable to ascorbic acid $\left(\mathrm{IC}_{50}=271 \mu \mathrm{g} \mathrm{mL}^{-1}\right)$.

The ferric reducing antioxidant power (FRAP) assay, which is within the technological reach of most laboratories, evaluates the reduction of $\mathrm{Fe}^{3+}$ to $\mathrm{Fe}^{2+}$ by the donation of an electron by the antioxidant, and it offers an accepted index of potential antioxidants ${ }^{28}$. In this study, there was a positive relationship between the concentrations of the plant extracts and the compound with absorbance (Fig. 1b). The MeOH extract of O. tenax had the highest reducing ability compared to the other extracts however; this was lower than ascorbic acid and $\alpha$-tocopherol. Moderate antioxidant activity was observed for the other extracts. Unlike the DPPH assay, $\beta$-sitosterol showed higher reducing ability than $\beta$-carotene.

The enzyme responsible for the digestion of dietary carbohydrates in the digestive tract of humans is $\alpha$-amylase by acting upon the linkage between the glucose units of carbohydrates. $\alpha$-Amylase hydrolyzes the carbohydrates to disaccharides then to glucose. Inhibition of this enzyme slows down the rate of digestion of carbohydrates, glucose absorption and thereby lowers blood glucose levels, consequently, reducing the postprandial increase of plasma glucose $e^{29}$. An inhibitor of $\alpha$-amylase reduces the conversion of carbohydrates to glucose. The effects of plant extracts and isolated compounds on the inhibition of $\alpha$-amylase are presented in Fig. 2a. The results showed the response to be dose-dependent. The $\mathrm{MeOH}$ extract $\left(\mathrm{IC}_{50}=190 \mu \mathrm{g} \mathrm{mL}^{-1}\right)$ and DCM extract $\left(\mathrm{IC}_{50}=645 \mu \mathrm{g} \mathrm{mL}^{-1}\right)$ of $O$. tenax were shown to be more active than the reference standard, acarbose $\left(\mathrm{IC}_{50}=875 \mu \mathrm{g} \mathrm{mL} \mathrm{L}^{-1}\right)$. The results suggest that extracts from nettles possess constituents that are able to block the hydrolysis of 1,4 glycosidic linkage of starch into glucose ${ }^{30}$. $\beta$-sitosterol $\left(\mathrm{IC}_{50}=1009 \mu \mathrm{g} \mathrm{mL} \mathrm{L}^{-1}\right)$ had a lower $\mathrm{IC}_{50}$ value compared to $\beta$-carotene $\left(\mathrm{IC}_{50}=1303 \mu \mathrm{g} \mathrm{mL}-1\right.$ ). These two compounds were found in $O$. tenax indicating synergistic effects for antidiabetic activity. Extracts of $L$. alatipes showed inhibition of $\alpha$-amylase but this was lower than acarbose.

The inhibition of $\alpha$-glucosidase activity of the extracts and compounds from nettles is presented in Fig. $2 b$. This enzyme is located in the small intestines, catalyzes the digestion and absorption of glucose into the intestines. Inhibition of $\alpha$-glucosidase decreases the digestion of carbohydrates, thereby decreasing postprandial blood 
a)
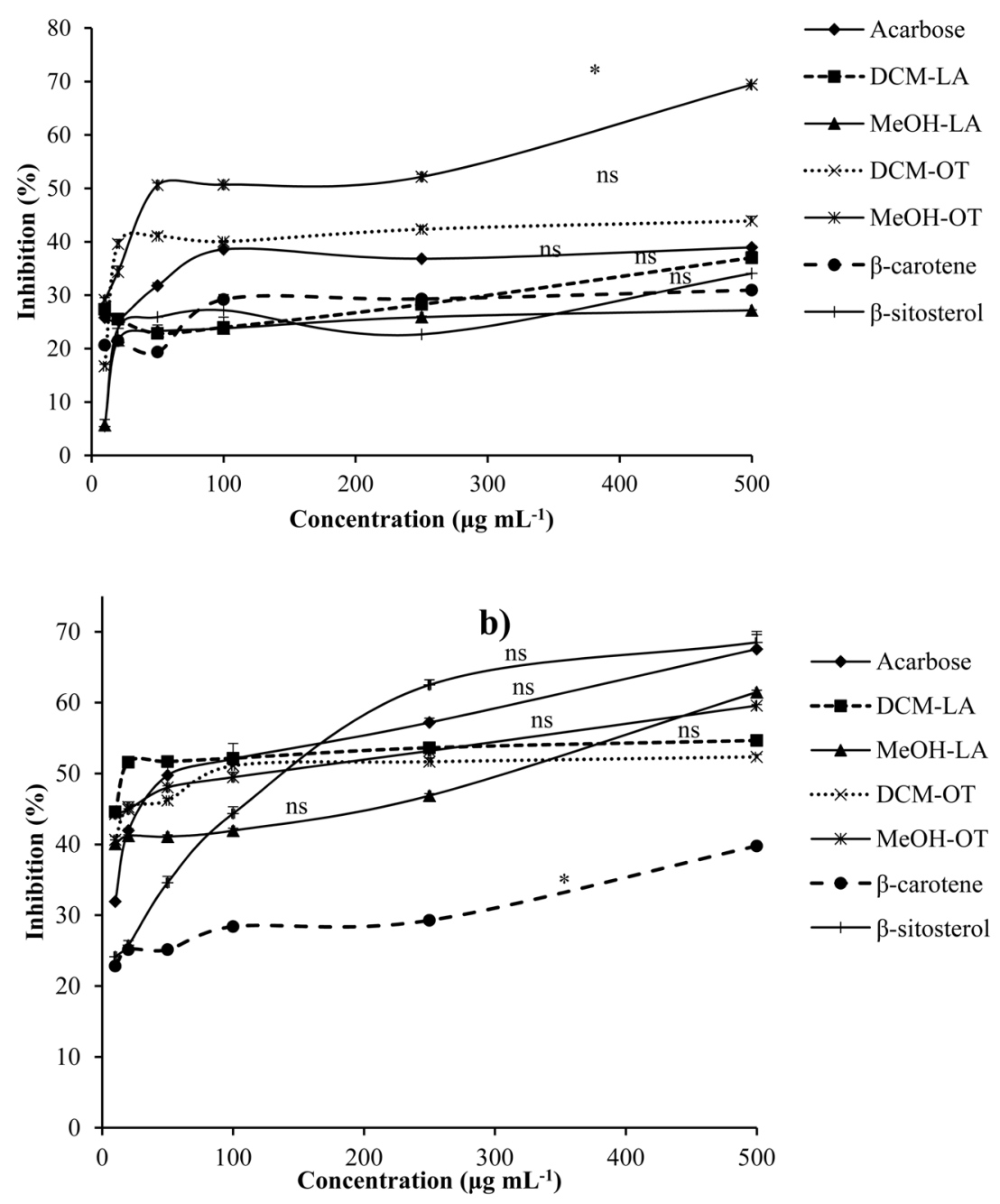

Figure 2. (a) Alpha amylase and (b) Alpha glucosidase inhibitory activity of L. alatipes (LA), O. tenax (OT) and isolated compounds. Values represented as mean $\pm S D, n=3$; One way Anova and Dunnetts post hoc test shows significant difference from positive control, acarbose (ns- not significant and $* p<0.05$ ).

glucose levels. There was moderate inhibition of $\alpha$-glucosidase compared to $\alpha$-amylase by $O$. tenax. The inhibitory potential of the DCM extract of $L$. alatipes $\left(\mathrm{IC}_{50}=42 \mu \mathrm{g} \mathrm{mL} L^{-1}\right)$ was lower than acarbose $\left(\mathrm{IC}_{50}=154 \mu \mathrm{g} \mathrm{L}^{-1}\right)$. $\beta$-Sitosterol $\left(\mathrm{IC}_{50}=229 \mu \mathrm{g} \mathrm{mL}^{-1}\right)$ was a more active inhibitor of $\alpha$-glucosidase compared to $\beta$-carotene. Previous studies on antidiabetic potential of plants from the Urticaceae family have shown promising results; extracts from Urtica dioica were reported to have antidiabetic effects in male rats with fructose-induced insulin resistance and aqueous extracts of Laportea ovalifolia were found to have antihyperglycaemic activity on alloxan diabetic rats ${ }^{31,32}$.

\section{Conclusion}

The results showed cooking to reduce the elemental and vitamin concentrations in nettles, which are temperature and time dependent. This reduction in concentration is significant when considering potential metal toxicities due to metals such as $\mathrm{Cd}$ and $\mathrm{Pb}$. The radical scavenging activity of the nettles was due to the presence of bioactive molecules in the plant with $\beta$-carotene having the highest activity. The FRAP assay indicated synergistic effects as the $\mathrm{MeOH}$ extract of $O$. tenax exhibited the highest ferric reducing power. The extracts of the leaves of $O$. tenax had higher $\alpha$-amylase inhibitory activity whilst those of $L$. alatipes had higher $\alpha$-glucosidase inhibitory activity. This study underscores the prospective antidiabetic properties of nettles; however, further studies are required to confirm this biological activity. Overall, our study supports the consumption of nettles for nutritional benefit and highlights their potential as nutraceuticals.

Received: 10 November 2019; Accepted: 2 June 2020;

Published online: 17 June 2020 


\section{References}

1. Rubatzky, V. E. \& Yamaguchi, M. Importance of vegetables in human nutrition in World vegetables: Principles, production, and nutritive values (eds. Rubatzky, V. E. \& Yamaguchi, M.) 34-41 (Springer US (1997).

2. Latham, M. Human nutrition in the developing world. (FAO (1997).

3. Puoane, T. et al. Chronic non-communicable diseases in South Africa: Progress and challenges. S. Afr. Health Rev. 2012/2013 $115-126$ (2012).

4. World Health Organization (WHO). Healthy diet. https://www.who.int/news-room/fact-sheets/detail/healthy-diet (2018).

5. Dasgupta, A. \& Klein, K. Fruits, vegetables, and nuts in Antioxidants in food, vitamins and supplements (eds. Dasgupta, A. \& Klein, K.) 209-235 (Elsevier (2014).

6. American Diabetes Association. Diagnosis and classification of diabetes mellitus. Diabetes Care 27, s5 LP-s10 (2004).

7. IDF (International Diabetes Federation). IDF diabetes atlas. www.diabetesatlas.org (2017).

8. Phillips, R. Wild Food: A complete guide to foragers. (Macmillan (2014).

9. Warren, P. 101 uses of Stinging Nettles. (Wildeye (2006).

10. Mahlangeni, N. T., Moodley, R. \& Jonnalagadda, S. B. The distribution of macronutrients, anti-nutrients and essential elements in nettles, Laportea peduncularis susp. peduncularis (River nettle) and Urtica dioica (Stinging nettle). J. Environ. Sci. Health, Part B. 51, 160-169 (2016).

11. WHO (World Health Organization). International programme on chemical safety: Cadmium. who.int/ipcs/assessment/public health/cadmium/en/ (2020).

12. Wani, A., Ara, A. \& Usmani, J. Lead toxicity: a review. Interdiscip. Toxicol. 8, 55-64 (2015).

13. FAO (Food and Agriculture Organization) \& WHO (World Health Organization). Joint FAO/WHO food standards programme Codex committee on contaminants in foods. 13-15 www.fao.orgcf05_INFPDF (2011).

14. Institute of Medicine Food and Nutrition Board. Dietary Reference Intakes for Calcium and Vitamin D. (The National Academies Press (2011).

15. WHO (World Health Organization). Fruit and vegetables for health: report of the Joint FAO/WHO Workshop on Fruit and Vegetables for Health, 1-3 September 2004. (WHO (2005).

16. Naude, C. E. Food-based dietary guidelines for South Africa: The "Eat plenty of vegetables and fruit every day. S. Afr. J. Clin. Nutr. 26, 46-56 (2013).

17. WHO (World Health Organization) \& FAO (Food and Agriculture Organization). Food energy - methods of analysis and conversion factors. FAO Food and Nutrition Paper (WHO/FAO (2002).

18. Bruulsema, T., Heffer, P., Welch, R., Moran, K. \& Cakmak, I. Fertilizing crops to improve human health: A scientific review fertilizing crops to improve human health. Food Nutr. Secur. 1, 1-8 (2012).

19. Phatlhane, D. V. et al. The iron status of a healthy South African adult population. Clin. Chim. Acta. 460, 240-245 (2016).

20. Food and Drug Administration. A food labelling guide: Guidance for industry. www.fda.gov/regulatory-information/search-fdaguidance-documents/guidance-industry-food-labeling-guide (2013).

21. Cruz, R. \& Casal, S. Validation of a fast and accurate chromatographic method for detailed quantification of vitamin $\mathrm{E}$ in green leafy vegetables. Food Chem. 141, 1175-1180 (2013).

22. Igwemmar, N. C., Kolawole, S. A. \& Imran, I. A. Effect of heating on vitamin C content of some selected vegetables. Int. J. Sci. Technol. Res. 2, 209-212 (2013).

23. Tian, J. et al. Domestic cooking methods affect the phytochemical composition and antioxidant activity of purple-fleshed potatoes. Food Chem. 197, 1264-1270 (2016).

24. Bernhardt, S. \& Schlich, E. Impact of different cooking methods on food quality: retention of lipophilic vitamins in fresh and frozen vegetables. J. Food Eng. 77, 327-333 (2006).

25. Bramley, P. et al. Review: Vitamin E. J. Sci. Food Agric. 80, 913-938 (2000).

26. Kedare, S. B. \& Singh, R. P. Genesis and development of DPPH method of antioxidant assay. J. Food Sci. Technol. 48, 412-422 (2011).

27. Krishna, C. S., Thankarajan, S. \& Thangaraj, P. Evaluation of nutraceutical properties of Laportea interrupta (L.) Chew. Food Sci. Biotechnol. 23, 577-585 (2014).

28. Menon, S., Rajeshkumar, S. \& Venkat Kumar, S. A review on biogenic synthesis of gold nanoparticles, characterization, and its applications. Resour.-Effic. Technol. 3, 516-527 (2017).

29. Afrisham, R., Aberomand, M., Ghaffari, M. A., Siahpoosh, A. \& Jamalan, M. Inhibitory effect of Heracleum persicum and Ziziphus jujuba on activity of alpha-amylase. J. Bot. 2015, 1-8 (2015).

30. Dutta, J. \& Kalita, M. C. In vitro hypoglycaemic evaluation of seven culinary plants of north east India against type 2 diabetes. Asian J. Pharm. Clin. Res. 9, 209-212 (2016).

31. Ahangarpour, A., Mohammadian, M. \& Dianat, M. Antidiabetic effect of hydroalcholic Urtica dioica leaf extract in male rats with fructose-induced insulin resistance. Iran. J. Med. Sci. 37, 181-186 (2012).

32. Momo, N. E. C., Fomekong, G. D. I., Tazoo, D., Etienne, D. \& Oben, J. E. Effect of aqueous and methanol/methylene-chloride extracts of Laportea ovalifolia (Urticaceae) on blood glucose level in rats. Pharmacologyonline. 118, 105-118 (2007).

\section{Acknowledgements}

We are grateful to Unathi Bongoza of the instrumental laboratory and Vuyiswa Mzozonyana of the NMR spectroscopy unit in the Chemistry department (UKZN). We also are grateful to the National Research Foundation (NRF) for their funding grant numbers (Roshila Moodley 114008, Nomfundo T. Mahlangeni 83791).

\section{Author contributions}

Dr. Nomfundo Thobeka Mahlangeni was the principal investigator and lead author writing up the manuscript. Dr. Roshila Moodley was the supervisor of the project and editor of the manuscript; she is the corresponding author. Prof. Sreekantha Babu Jonnalagadda was the budget owner and supervisor of the project.

\section{Competing interests}

The authors declare no competing interests.

\section{Additional information}

Supplementary information is available for this paper at https://doi.org/10.1038/s41598-020-67055-w.

Correspondence and requests for materials should be addressed to R.M.

Reprints and permissions information is available at www.nature.com/reprints.

Publisher's note Springer Nature remains neutral with regard to jurisdictional claims in published maps and institutional affiliations. 
(c) (i) Open Access This article is licensed under a Creative Commons Attribution 4.0 International License, which permits use, sharing, adaptation, distribution and reproduction in any medium or format, as long as you give appropriate credit to the original author(s) and the source, provide a link to the Creative Commons license, and indicate if changes were made. The images or other third party material in this article are included in the article's Creative Commons license, unless indicated otherwise in a credit line to the material. If material is not included in the article's Creative Commons license and your intended use is not permitted by statutory regulation or exceeds the permitted use, you will need to obtain permission directly from the copyright holder. To view a copy of this license, visit http://creativecommons.org/licenses/by/4.0/.

(C) The Author(s) 2020 